\title{
Digitalization of Modern Education: Problems and Solutions
}

\author{
https://doi.org/10.3991/ijet.v16i04.18203
}

\author{
Natalia Ronzhina ${ }^{\bowtie}$, Irina Kondyurina, Alla Voronina, \\ Konstantin Igishev, Natalya Loginova \\ Russian State Vocational Pedagogical University, \\ Ekaterinburg, Russia \\ obrpravo@yandex.ru
}

\begin{abstract}
The relevance of the research topic is due to modern global digital transformations and the transition to the digital economy and digital society. Social digitalization is caused by qualitative technological changes. All over the world, digitalization in education is closely related to a new way of life in a digital environment and the emergence of generations who were born and study in the specific environment. The study was based on a survey assessing the quality of digitalization in education, which involved 475 students and 118 teachers of the Russian State Vocational Pedagogical University (Yekateringburg). Based on the analysis of modern research on digital education, the most important components of digitalization have been identified and assessed in the survey. The survey was based on a Likert scale; the importance of each significant aspect of digitalization was assessed from 0 to 10. Unanimously, the research participants rated the level of penetration of digital technologies into Russian higher education as low: 3.15 (students) and 3.43 (teachers). The contribution of digitalization to academic performance was rated above average ( 7.25 and 5.21, respectively). There were some differences in the assessment of the role of the teacher in the digital environment (4.65 and 7.14), the convenience of the digital environment (7.11 and 2.53) and its positive impact on student motivation ( 8.09 and 3.61 , respectively). The increase in the cognitive capabilities of students due to digitalization was also differently assessed by the students and teachers (6.88 and 3.11, respectively). Thus, digitalization in Russian universities generally reflects the expectation of its future development and a positive student attitude to the available opportunities. The novelty of the research is an attempt to objectively assess the internal process of digitalization and determine further research directions. In practice, the study can reform the education system, accelerate and improve the process of higher education digitalization.
\end{abstract}

Keywords-Digitalization, vocational education, digital transformation, digital education, personalization of education 


\section{Introduction}

The relevance and significance of the digital transformation of the educational process is caused by the global processes of the transition to the digital economy and digital society. The digital way of life, like any new technological order, opens up new socio-economic prospects for the society and provides people with new opportunities. It has been generally accepted that the digital transformation of society is changing the global landscape, the role and opportunities of the student in this world (especially in the world of professions) [1]; new types of activity that expand the boundaries of the modern world appear; new technologies change the instrumental capabilities of the economic subject; the role of motivational and value attitudes and moral-ethical qualities of the individual also increases [2,3].

The digital economy is being registered and legitimized at the level of international agreements on a new economic order. In particular, this refers to the 2016 Ministerial Meeting held in June 22-23, in Cancun (Mexico), which was attended by the ministers of the Organization for Economic Cooperation and Development (OECD), the European Union and a number of other countries (Russia was not included). This meeting is considered as a benchmark of the modern purposeful movement towards the digital transformation of modern society [4]. The basic idea of the Ministerial Declaration on the digital economy was the recognition of the digital development of the world economy, the growing use of and investment in digital technologies and capital, as well as the recognition that the digital economy acts as a powerful catalyst for innovation, growth and well-being of citizens. A special focus is placed on the relationship of the digital economy with the digitalization of education as people must have certain skills to participate in the digital economy and digital society.

A number of studies are devoted to the relationship between the economy and education in the modern digital world; they examine the features of the development of practical skills and competencies of students based on case studies in the digital economy. People working in the digital environment should be able to create and process complex information; think systematically and critically; be creative, and able to solve real problems of the digital world $[5,6]$.

According to research, in 2017, the share of the digital economy in Russia was $3.9 \%$ while in the USA and China the indicators were $10.9 \%$ and $10 \%$, respectively. Economists believe that highly digitized economies are characterized by more efficient economic, social and other spheres; they also have great opportunities to invest in the social sphere due to the efficient production rate, high added value, regular budget contributions, etc. [7].

In a number of studies, the issue of the development of digital education is closely related to the introduction and implementation of the artificial intelligence technology in the daily life [8]; the advent of native digital generations, people who reside in the digital environment, dramatic changes associated with career guidance, multiple changes in employment and lifelong learning [2,9]. The issue of the ambiguity of human interaction with the digital environment and its negative impact on cognitive abilities, attention, and other aspects of human life is of particular importance [10]. 
The first attempts to comprehend the challenge of the digitalization of education in Russia, its possible solutions, and priority tasks to modernize education are described in a multi-author book edited by Gorbunov [11]. It discusses the institutional changes in modern society driven by digitalization, considers the issues of the development of a digital educational environment, and analyzes the changes in educational technologies used in the vocational school. Today digital technologies affect all spheres of public life: business, communication, healthcare, travel, education. Digitized education can transform any country by developing human resources and increasing the productivity of the state [12].

The purpose of the study is to describe an integrated approach to the concept of "digitalization of education" and its implementation in the educational process. The research objectives are as follows: comparative analysis of the digitalization of education in Russia and abroad; identification of the characteristics of the concept of the "digitalization of education"; identification of the differences between the concepts of "distance education", "online education", and "e-learning"; assessment of the level of implementation of digital technologies in general and vocational education. The study has a practical focus and can be used to improve the processes of digitalization of the Russian higher education.

\subsection{Literature review}

The analysis of modern scientific research on the digitalization of education allows us to conclude that many problems are common to a number of countries, including Russia; however, they often acquire their own national specifics due to different levels of economic and social development [7]. The studies conducted over the past decade prove that teacher training and digital competences, which are often better developed in native digitals than educators, play a crucial role [13].

Most Russian scholars are aware of the need to transform modern education within the framework of lifelong learning, i.e., at all levels of general and vocational education and self-education. Some Russian researchers note that new information and communication technologies are the pre-condition for the deployment of digital pedagogy [14].

Special attention is given to the development of digitalization in vocational pedagogy due to the fact that student success directly correlates with teacher competencies $[7,15]$. Digital practices, in particular, computer games, are widely used to involve schoolchildren and students in the learning process [16]. In Russia, there are also digital transformation plans, for example, patterns aimed to improve the quality of economic education in Russia. Akimutina [17] believes that the creation of situational centers for digital management of education in the regions is feasible; she notes that they will make it possible to competently make decisions in crisis situations, as well as reduce labor costs associated with collecting, processing and storing data.

Foreign studies on the digitalization of education describe the general consensus of scientists that digital technologies are an integral part of the modern learning process. The European Commission is developing a number of policy initiatives to modernize education and vocational training, fund research and innovation to advance digital 
technologies used for learning, and assess the digitalization of education [18]. The foreign experience of the higher education digitalization is studied and applied in the Russian Federation; it is described in the study by Kochergin and Zhernov [19].

The analysis of foreign scientific research on digitalization allows us to make the following conclusions: the evolution of the education industry and its development features in the 21 st century based on the transition from the "old school" to the "new school" occurs due to digitalization [20]. The digitalization of education affects the education ecosystem [21]. Sukhomlin [4] also highlights the importance of digital skills in the ecosystem of the digital economy and shows the feasibility of deploying a national system aimed at the development of digital skills based on open educational practices, i.e. a system that implements educational practices based on international educational standards in the field of information technology. Le [22] focuses on computer-based learning aimed at the development of critical thinking and identifies the shortcomings of this technology.

Foreign researchers discuss the digitalization of education in Finland, the role of digital transformations and the growth of educational technologies in the context of secondary education, the replacement of old teaching methods and practices with the new ones, the introduction of dramatic changes in instructions and the assesment methodology [23,24]. Näykki et al. [25] highlight growing opportunities for learning and interaction in the educational and professional contexts through technological innovations, such as social networks, educational games and digital technologies, etc. However, technological transformations can also carry the potential risk of neglecting the affective learning processes, i.e. processes associated with emotional sufferings and self-actualization of students in the learning process.

The researchers of the Curry School of Education and Human Development, University of Virginia (USA), have demonstrated an interesting experience. They analyzed the effectiveness of online courses compared to intramural attendance in terms of the success and motivation of students to study. The results of the study showed that students studying online had poorer performance and experienced more difficulties compared to intramural students. There were no significant differences in student motivation in the experimental groups [26].

Foreign and domestic researchers note that the digitalization of education has significantly changed the relationship between the teacher and the student. This is due to the fact that today the student has free access to various sources of information, as opposed to the traditional model of education, and therefore teaching methods should be more interactive and attractive based on digital technologies [13,27,28]. Digitalization does not completely eliminate the human factor in education; it defines a new place and qualifications of teachers in a digital society and the education system [5]. The teacher should not be a knowledge transmitter, but a mentor and facilitator, whose task is to help students adapt and apply the knowledge gained. In Russia and abroad, there is a great fear of change and the loss of selfhood; a focus on stability and a lack of strategic vision [2].

In domestic and foreign studies, there is no unequivocal opinion on the role and the place of digitalization in the educational process. While recognizing that digital technologies have changed modern education, scientists highlight the fears and doubts of 
educators about how or even whether to include them in teaching [29]. However, the failure to integrate technologies into the educational process can do a disservice to students when they enter the labor market. Analyzing the problems of the digitalization of education, researchers note some negative consequences for schoolchildren and students that arise during its implementation; they are the loss of mental abilities (ability to perceive large texts without delving into the content), screen addiction, decreased social skills and the development of cancer [8,9]. According to Shipp and Noula [30], digitalization is transforming educational opportunities starting from the initiatives to provide basic education to the programs in the world's leading educational institutions. They argue that relevant skills and familiarity with the digital ecosystem are required; however, there is also a need for the third outcome to have a better digital life. Thus, it is important to bring up citizens who are inspired, motivated, and equipped to challenge the institutional power and change the world. The researchers concluded that students having a digital background were more likely to meet employers' expectations. Modern digital technologies support student learning on the scale that was previously unimaginable through individualized instruction methods to cater to the needs of every student. Informational and intellectual support helps teachers adapt their activities to the needs of individual students so that they receive proper advice at the right time [30].

Both developed and developing countries should deal with the digitalization of education [31]. Kalolo [31] highlights the fact that the digital era around the world has proven its ability to transform most educational processes and systems, including the educational systems of developing countries (including Tanzania). Considering the infrastructure and resource problems in the region, the researcher places the focus on the attempts to bridge the knowledge gaps associated with digital technologies in education and describes problem areas and promising approaches to their solution. Learning Management Systems (LMS) allow students to access any online course and resource to receive on-demand assistance beyond the physical reach of their instructors [32]. At the same time, there is a consensus of opinion that the digitalization of economy and education is the future; economic and educational processes are interconnected and objectively conditioned by the overall development of the world and civilization that brings a new vision of and attitude to the education system, new forms, and means of education. Therefore, there is a need to include new digital technologies in these processes.

\section{Methods}

\subsection{Methods}

Based on the analysis of the methodological approaches described in the economic and pedagogical literature, a group of assessment parameters was defined; in our opinion, they are the most consistent with the research problem related to the quality of the digitalization of higher education. The parameters were determined by refining the research concepts and methodologies based on the latest practical research in this 
area $[1,10,15]$. The study was based on surveying a statistically significant sample of representatives of a higher educational institution and comparing the assessments of the digitalization process by the teaching staff and students.

\subsection{Participants}

The research took place at the Russian State Vocational Pedagogical University (Yekateringburg). The research is based on the survey of two groups of participants: 375 students and 118 teachers. The research sample consists of students of all fulltime courses aged 18 to 23 (187 men and 188 women, 19 specialties) and teachers aged 30 to 64 (59 men and 59 women, 16 departments and 5 institutes of the educational institution). The research sample was randomly designed in order to involve the most representative group of students and teachers to obtain the most reliable assessment of the digitalization of education in the Russian Federation through the example of the university involved. Given the impossibility of establishing the value of the sample attribute and based on the general population, the reliability of the sample is 0.498 (student sample) and 0.328 (teacher sample).

\subsection{Data analysis}

The participants were asked to assess each questionnaire item on a 10-point scale, where 0 is the negative assessment or complete disagreement with the statement, and 10 is complete agreement with the statement. When statistically processing the results of the survey, the average value of each aspect was calculated, as well as the standard deviation. The deviation was studied to establish the dispersion of the respondents' opinions on the item. The Pearson correlation coefficient was calculated between every two questionnaire items of both the student questionnaire and the teacher questionnaire in order to establish possible relationships between them.

\subsection{Statistical processing}

Statistical processing and analytical research of the survey results was performed in SPSS Statistics 22; the results were visualized in MS Excel 2013. Based on the survey results processing, the percentages of the answers were determined, as well as the standard deviation for each answer, and the Pearson correlation coefficients between every two answers. The results that showed a significant statistical correlation were used in the study.

\subsection{Ethical issues}

Teachers and students were invited to participate in the study by sending invitations to the departments and by e-mail. The anonymity was guaranteed. If the participant accepted the invitation, he or she was assigned a unique identifier to process his 
or her questionnaire. Thus, we did not get access to any personal data of the participants and were confident that they complied with the sampling requirements.

\subsection{Research limitations}

The study considers one large Russian university and describes reliable results; however, they require clarification on the example of other universities located in different regions and a sample involving different social and ethnic groups of the participants. In addition, the study does not address gender differences or assessments by foreign students, which may be the subject of further study.

\section{$3 \quad$ Results}

The analysis of the correlation between the answers of teachers and students showed a low negative value $(-0.28)$. Thus, there is no statistically significant relationship between the assessments of the digitalization of education by teachers and students.

According to the teacher assessment of the digitalization of education (Fig. 1), the most significant factor is still teacher participation (7.14) while the convenience of digital educational tools is low-rated ( 0.23 at the minimum standard deviation of 0.44 , which indicates the high unanimity). The impact of digitalization on student motivation and the improvement of the cognitive abilities of students was also assessed as minor (3.61 and 3.11, respectively). At the same time, the effect of digital education on the academic performance improvement is much higher (5.11 at the maximum standard deviation of 1.46). This suggests that the opinion of the teachers is more divided on this issue than on any other. We have a hypothesis to be tested that in this case the range of assessments may be related to the age of teachers and their personal digital literacy.

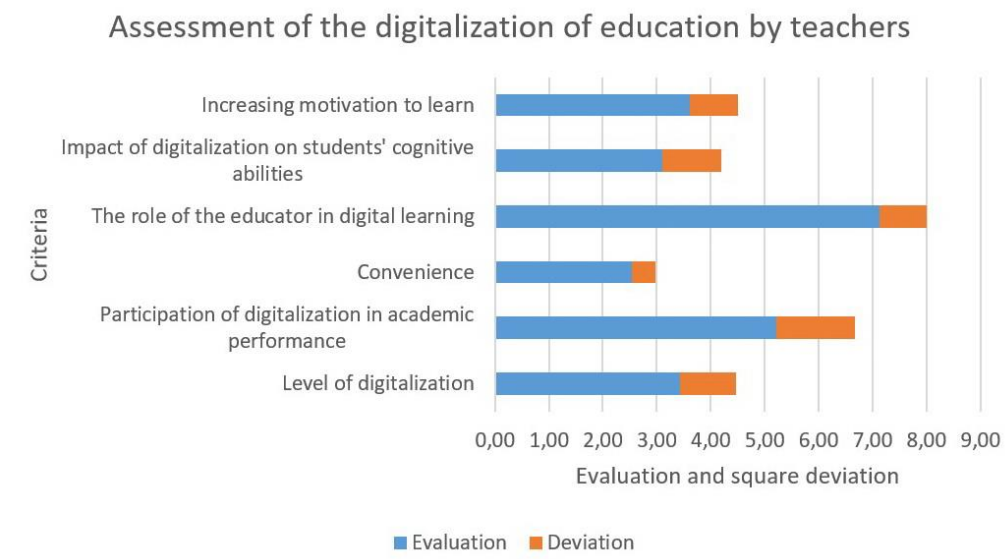

Fig. 1. Teacher assessment of the digitalization of education 
Student assessment of the digitalization of education is described in Fig. 2. On average, student assessments were higher compared to the ones given by teachers even with the standard deviation. The teacher and student assessment of the overall penetration of digital technologies into the educational process was quite identical (3.43 and 3.15 within the mutual statistical error, respectively). The effect of digitalization on academic performance (7.25 at the deviation of 2.42) was also highly assessed. That is, students and teachers have no consensus on the assessment of this parameter. The greatest difference between the assessments relates to the effect of digitalization on the cognitive capabilities of students. According to the teachers, the effect is relatively poor while the students find it one of the strongest (6.88). According to the students, the increase in motivation to study is most affected by digitalization (8.09); this is the highest average assessment in the student questionnaire. The student assessment of the convenience of digital learning was also much higher (7.11 at the very low deviation of 0.98 ).

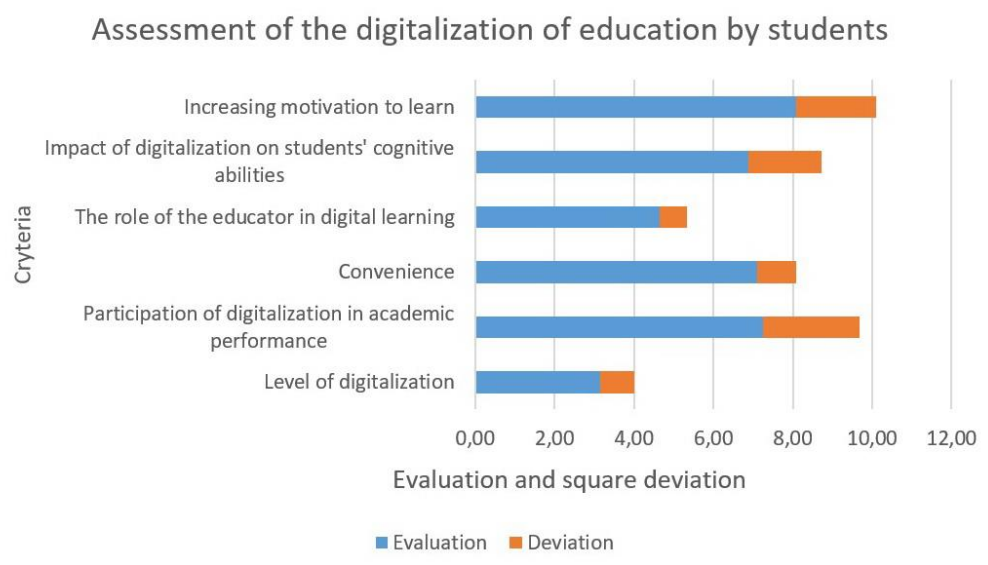

Fig. 2. Student assessment of the digitalization of education

Further research should be aimed at the study of the differences between the assessments of the impact of digitalization on the motivation of students and their cognitive abilities. Based on the results of similar studies, it can be assumed that students are more emotionally involved in digital life and they positively assess any electronic communication regardless of the results produced. The same applies to assessing the convenience of digital educational tools that have already been introduced in the Russian higher education system. The difference between the assessments of teachers and students is apparently due to different levels of digital literacy and the regularity of using the digital environment. This may also be evidenced by the low standard deviation of this parameter in the student assessment and the high one in the teacher sample that is characterized by a significant age range. Older people still experience difficulties when using the digital environment and digital educational tools [13]. Thus, the assessment of motivation may be accurate due to the fact that it is given by the one 
who is motivated (the student) while the assessment of the impact of digitalization on cognitive abilities requires independent verification.

In general, we can conclude that both students and teachers gave a relatively low assessment to the penetration of digital technologies into the educational process, but at the same time they rated the quality and positive impact of this process on the achievement of personal and pedagogical goals as average or high. With due regard to the differences between the assessments, we can conclude that this is an assessment of positive expectations rather than actual results; however, this form of pedagogy is rapidly developing and quickly providing the expected results.

\section{Discussion}

Research on digitalization has been carried out in a number of foreign studies over the past years; their review shows that this process is dubious in almost all countries regardless of their economic and social development level $[2,10]$. There are very few studies devoted to the integral assessment of the digitalization process and its components. More often, the projects to improve certain elements of this process are offered; these include online learning, mobile learning, mixed methods of teaching, the use of cloud technologies, etc. All these technologies are independently implemented in accordance with specific needs. Therefore, in order to give an integral assessment of the digitalization process, we share the opinion of other researchers and highlight the need to determine the concepts of digitalization [8].

Foreign research also considers the conceptual apparatus associated with digital learning: mobile learning, one-to-one learning, synchronous and asynchronous online courses (the right balance between synchronous learning that allows student collaboration and asynchronous learning focused on individual activities) [33,34]. Shaffer [33] prefers automated knowledge assessment and discusses the importance of computer-based learning and intellectual tutoring to improve teaching; he defines the problem of online education (massive open online courses) while considering other problems that are common to both foreign and Russian education systems.

The asynchronous approach to the educational process involves the upload and transfer of the educational content within the educational program, its independent study by students, and electronic reporting to the teacher according to the personalized course schedule. The synchronous approach involves real-time training based on distance learning technologies (DOT) through video conferencing, chats and webinars. A webinar can be conducted within the framework of the traditional extra-mural course or distance learning, which involves a web conference followed by the teacher and student feedback [7].

A special focus is placed on the concept of distance learning; it is defined as training based on information technologies and telecommunication networks that indirectly accompany (at a distance) the student and sometimes completely exclude face-toface teacher feedback.

The concept of an online course should be distinguished; this is a collection of electronic educational resources for organizing and supporting the educational process 
in a digital environment of an academic discipline. The concept of e-learning involves educational activities (regardless of the form of education) that require the use of electronic databases and information, tools for processing and transmitting information through certain communication lines, active interaction between the teacher and the student in a digital environment.

These elements are gradually being integrated with each other to make up a common pedagogical system, which may create a truly digital learning environment. According to some researchers, this system integrates secondary, primary and preschool education [8]. This process is also observed in the educational institution, where we conducted our study; however, it is lengthy and is slowed down by a number of factors.

Russian researchers are more cautious about digitalization. Manikovskaya [35], Machekhina [36] are concerned about the elimination of the educational, personal, and axiological aspect from the educational process. Other researchers believe that technologization and pragmatization of modern educational content are clearly observed in education; this should not exclude a close cognitive and creative interaction between the teacher and the student [14,37]. Enikeeva and Enikeev [38] believe that digital changes will enrich the educational activities of Russian educational organizations and make education more accessible.

A comparative analysis of foreign and domestic studies devoted to the digitalization of education shows that the scientific community is aware of the need and complexity of these changes and their direct inclusion in the educational process. In foreign research, the emphasis is shifted towards the introduction of digital technologies in education while Russian studies describe the phenomenological and technological approaches. The difference between Russian and foreign studies is the fundamental approach to the solution of such a complex social and state problem in the field of education. This is due to the special vision of the student in the education system, the approach to the personality as a certain phenomenon and value, and therefore a special attitude towards various changes, reforms, and innovations both in society and education as it is education that forms personality, the worldview and general attitude to the world.

The low assessment of the teacher role in the digital learning environment in our study is closely related to the problems of transforming teaching methods. A lot of experience in teacher training and mutual learning has been gained and the social tension of digitalization of all spheres of life has been successfully eliminated $[3,6,8]$. The digitalization of the educational process (the use of e-learning and distance learning technologies, the development and implementation of online courses, etc.) has a significant impact on the teacher.

In our study, the low assessment of the digital changes implemented in education correlates with the current problems of the Russian education system. The legislation governing teacher work does not reflect the increasing requirements for teachers associated with the digitalization of education. This is one of the reasons that impedes the introduction of digital technologies into the educational process. This problem cannot be solved by improving the qualifications and digital literacy of teachers. The introduction of large-scale changes requires the creation of appropriate conditions for the 
immediate performers. In this regard, the teaching load of 900 hours assigned to teachers seems to be unacceptably high as they have to work in the conditions of a rigidly increasing labor intensity; this does not allow educators to actively participate in the implementation of projects on the digitalization of the educational process [39]. The established teaching load impedes the digitalization of the educational process as it is a laborious process both in terms of time and the development of the educational content. It is no coincidence that today Russian universities do not have significant achievements in this area.

\section{Conclusion}

The generalization of foreign and domestic research devoted to the issue of the digitalization of higher education allows us to make a conclusion about the generality and relevance of the problem, both from the perspective of the implementation of technologies and their scientific and theoretical conceptualization, i.e. a reasonable combination of classroom, personalized and distance learning; the use of digital technologies in accordance with the purpose of the lesson, etc. The studies on the digitalization of education are quite diverse and generally have a political aspect (they describe events accompanying the introduction of digital technologies in education), a regulatory aspect (the analysis of regulatory legal acts and legal documents governing the digitalization process in the country), a technological and psychological aspect (the teacher's readiness to be trained to develop and implement digital educational content), an axiological aspect (technologization and humanization of the educational process), etc.

The study was based on a survey assessing the quality of digitalization in education, which involved 475 students and 118 teachers of the Russian State Vocational Pedagogical University (Yekateringburg). The survey was based on a Likert scale; the importance of each significant aspect of digitalization was assessed from 0 to 10 . Both students and teachers gave a relatively low assessment to the penetration of digital technologies into the educational process ( 3.15 and 3.43, respectively). At the same time, the contribution of digitalization to academic performance was rated above average (7.25 and 5.21, respectively). The difference between the student and teacher assessments was observed in the assessment of the teacher role in the digital environment (4.65 and 7.14, respectively; the teachers rated their role much higher), the convenience of the digital environment (7.11 and 2.53, respectively) and its positive impact on student motivation (8.09 and 3.61 respectively). The increase in the cognitive capabilities of students due to digitalization was also differently assessed by the students and teachers (6.88 and 3.11, respectively). Thus, digitalization in Russian universities generally reflects the expectation of its future development and a positive student attitude to the available opportunities.

The study aims to improve the education system and accelerate the digitalization of higher education, which will provide the digital economy with competent personnel. 


\section{Acknowledgement}

Not applicable.

\section{$7 \quad$ References}

[1] Esteve-Mon, F., Llopis, M., Adell-Segura, J. (2020). Digital Competence and Computational Thinking of Student Teachers. International Journal of Emerging Technologies in Learning, 15(2): 29-41. https://doi.org/10.3991/ijet.v15i02.11588

[2] Kaplan, A.M., Haenlein, M. (2016). Higher education and the digital revolution: About MOOCs, SPOCs, social media, and the Cookie Monster. Business Horizons, 59(4): 441450. https://doi.org/10.1016/j.bushor.2016.03.008

[3] Penprase, B.E. (2018). The fourth industrial revolution and higher education. In Higher education in the era of the fourth industrial revolution. Springer Nature, pp. 207-229. https ://doi.org/10.1007/978-981-13-0194-0_9

[4] Sukhomlin, V.A. (2017). An open system of IT education as a tool for the formation of digital skills. Strategic Priorities, 1(13): 70-81.

[5] Wildemeersch, D., Jütte, W. (2017). Digital the new normal-multiple challenges for the education and learning of adults. European journal for Research on the Education and Learning of Adults, 8(1): 7-20. https://doi.org/10.3384/rela.2000-7426.relae13

[6] Saputra, M., Al Siddiq, I.H. (2020). Social Media and Digital Citizenship: The Urgency of Digital Literacy in The Middle of a Disrupted Society Era. International Journal of Emerging Technologies in Learning, 15(07): 156-161. https://doi.org/10.3991/ijet.v15i07.13239

[7] Williamson, B. (2016). Digital education governance: An introduction. European Educational Research Journal, 15(1): 3-13.

[8] Seldon, A., Abidoye, O. (2018). The fourth education revolution. Legend Press Ltd.

[9] Emejulu, A., McGregor, C. (2019). Towards a radical digital citizenship in digital education. Critical Studies in Education, 60(1): 131-147. https://doi.org/10.1080/17508487.2016. $\underline{1234494}$

[10] Oberländer, M., Beinicke, A., Bipp, T. (2020). Digital competencies: A review of the literature and applications in the workplace. Computers \& Education, 146: 103752. https://doi. org/10.1016/j.compedu.2019.103752

[11] Gorbunov, N.V. (2019). Digitalization as a priority of the modernization of Russian education. Saratov Socio-Economic Institute, Saratov.

[12] Wadhwa, R. (2019). How Digitization can be a game-changer for India's Education Sector. https://www.entrepreneur.com/article/337947.

[13] Nielsen, W., Miller, K.A., Hoban, G. (2015). Science teachers' response to the digital education revolution. Journal of Science Education and Technology, 24(4): 417-431. https:// doi.org/10.1007/s10956-014-9527-3

[14] Safuanov, R.M., Lehmus, M.Yu., Kolganov, E.A. (2019). Digitalization of the education system. Bulletin of Ufa State Petroleum Technological University. Science, education, economics. Series: Economics, 2: 116-121.

[15] Ross, J. (2017). Speculative method in digital education research. Learning, Media and Technology, 42(2): 214-229. https://doi.org/10.1080/17439884.2016.1160927

[16] Lengyel, P.S. (2020). Can the Game-Based Learning Come? Virtual Classroom in Higher Education of 21st Century. International Journal of Emerging Technologies in Learning, 15(02): 112-126. https://doi.org/10.3991/ijet.v15i02.11521 
[17] Akimutina, A.A. (2019). Digitalization of education in the region based on the situational center model. In Socio-economic development of Russia: problems, trends, prospects: the collection of scientific articles of the 18th International Scientific and Practical Conference. Kursk Branch of the Financial University under the Government of the Russian Federation, Kursk, pp. 22-25. https://doi.org/10.24891/ni.15.5.909

[18] European Commission (2019). European Commission Digital Learning \& ICT in Education https://ec.europa.eu/digital-single-market/en/policies/digital-learning-ict-education .

[19] Kochergin, D.G., Zhernov, E.E. (2019). Digitalization of higher education in the USA. Professional education in Russia and abroad, 2(34): 12-23.

[20] Ainslee, J. (2018). Digitalization of Education in the 21st Century. https://elearning industry.com/digitization-of-education-21st-century .

[21] Deloitte (2019). Digital Education Survey. https://www2.deloitte.com/us/en/pages/techno logy-media-and-telecommunications/articles/digital-education-survey.html.

[22] Le, N-T. (2019). How do technology-enhanced learning tools support critical thinking? Frontiers Education, 4: 126.

[23] Newman, D. (2017). Top 6 Digital Transformation Trends in Education. https://www. forbes.com/sites/danielnewman/2017/07/18/top-6-digital-transformation-trends-in-educati on/\#23aa216c2a9a.

[24] Sipila, K. (2018). Digitalization of Basic Education: A Case Study from Kaarina, Finland, Part I. https://education.viewsonic.com/digitalization-basic-education-case-study-kaarinafinland-part/

[25] Näykki, P., Laru, J., Vuopala, E., Siklander, P., Järvelä, S. (2019). Affective Learning in Digital Education - Case Studies of Social Networking Systems, Games for Learning, and Digital Fabrication. Frontiers Education, 4: 128. https://doi.org/10.3389/feduc.2019.00128

[26] Francis, M.K., Wormington, S.V., Hulleman, C. (2019). The Costs of Online Learning: Examining Differences in Motivation and Academic Outcomes in Online and Face-to-Face Community College Developmental Mathematics Courses. Frontiers in Psychology, 10: 2054. https://doi.org/10.3389/fpsyg.2019.02054

[27] Gohil, P. (2018). Digital Education - The Future of Learning. Entrepreneur India. https:// www.entrepreneur.com/article/324081

[28] Padia, K. (2018). 5 Ways in Which Digital Education is Changing the Face of Education. https://www.digitaldoughnut.com/articles/2018/september/5-ways-in-which-digital-educat ion-is-changing-the.

[29] Digital Marketing Institute (2019). How to Use Digital Technologies to Teach Students. https://digitalmarketinginstitute.com/blog/how-to-use-digital-technologies-to-teach-studen ts.

[30] Shipp, J., Noula, I. (2017). What's the point of "digital education"? Education, citizenship and sustainable digital lives. LSE Media Policy Project. https://blogs.lse.ac.uk/medialse/ 2017/09/05/whats-the-point-of-digital-education-education-citizenship-and-sustainable-dig ital-lives/ https://doi.org/10.1093/obo/9780199756810-0264

[31] Kalolo, J.F. (2019). Digital revolution and its impact on education systems in developing countries. Education and Information Technologies, 24(1): 345-358. https://doi.org/10.1007/s10639-018-9778-3

[32] Taha, A.K. (2019). How Technology Can (and Does) Improve Education. https://www. trustradius.com/buyer-blog/how-technology-improves-education.

[33] Shaffer, C.A. (2014). Grand challenges in digital education. Frontiers in ICT, 1: 5.

[34] Mayer, R. (2008). Applying the Science of Learning: Evidence-Based Principles for the Design of Multimedia Instruction. American Psychologist, 63: 760-769. https://doi.org/10. $\underline{1037 / 0003-066 x .63 .8 .760}$ 
[35] Manikovskaya, M.A. (2019). Digitalization of education: challenges to traditional norms and principles of morality. Power and administration in the East of Russia, 2(87): 100-106.

[36] Machekhina, N.A. (2019). Digitalization of education: current state and forecast. Pedagogy issues, 3: 193-198.

[37] Afanasyev, A.A. (2018). Digitalization of education: the disadvantages of an electronic school. https://vc.ru/flood/43800-cifrovizaciya-obrazovaniya-vseminusyelektronnoy-shkol y-chto-budet-s-detmi .

[38] Enikeeva, S.D., Enikeev, I.Kh. (2019). The digitalization of higher education in Russia. In Digital transformation: education, science, society. Publishing House of the Central Research Institute of the Russian Sign Language, Moscow, pp. 203-213.

[39] Ministry of Education and Science of the Russian Federation (2014). Order of the Ministry of Education and Science of the Russian Federation "On the teaching load (hours of teaching work at the rate of pay) of the teaching staff and on the procedure for determining the teaching load of the teaching staff stipulated in the employment contract". https://legalacts. ru/doc/prikaz-minobrnauki-rossii-ot-22122014-n-1601/. https://doi.org/10.17720/2409-583 4.v3.1.2016.05p

\section{Authors}

Ronzhina Natalia Vladimirovna is a Doctor of Pedagogical Sciences, Professor of the Department of Law, Russian State Vocational Pedagogical University, Ekaterinburg, Russia.

Kondyurina Irina Mihailovna is $\mathrm{PhD}$ of Pedagogical Sciences, Associate Professor of the Department of of Russian and Foreign Languages, Russian State Vocational Pedagogical University, Ekaterinburg, Russia.

Voronina Alla Arkadyevna is $\mathrm{PhD}$ of Law, Head of the Department of Law, Russian State Vocational Pedagogical University, Ekaterinburg, Russia.

Igishev Konstantin Andreevich is an Assistant of the Department of Law, Russian State Vocational Pedagogical University, Ekaterinburg, Russia.

Loginova Natalya Evgenievna is a Master Student of Russian State Vocational Pedagogical University, Ekaterinburg, Russia.

Article submitted 2020-09-02. Resubmitted 2020-10-22. Final acceptance 2020-10-24. Final version published as submitted by the authors. 